\title{
THE EVALUATION OF INTENSIVE MUNICIPAL ECONOMIC ENTERPRISES IN LOCAL GOVERNMENTS FROM THE POINT OF VIEW OF PUBLIC BENEFIT
}

\author{
Murat ÇAK $^{1}$
}

\author{
Binhan Elif YILMAZ²
}

\author{
Volkan OĞHAN ${ }^{3}$
}

\begin{abstract}
Today, municipalities, which are a local government unit, are provided with legal and financial opportunities to meet the common local needs and to fulfill the relevant services. However, the municipalities prefer the way of corporatization with the settlements such as Municipality-Owned Enterprises (MOEs), subsidiary company, and partnership in fulfilling services and rendering of various goods and services. Through the application of MOEs, which offers an alternative to municipalities in the case of income generation, it provides operating in market economy according to market conditions in line with the increase in local public benefit of a public entity. Public correlation in the state of establishment and management of MOEs may cause them to be in a different status than other actors of the market. MOEs are established according to the reasons such as efficient and local service delivery through privatization, the use of opportunities and techniques in market economy without bureaucratic processing burden, benefiting the flexible wage policy and skilled labor, reducing the effect of centralized administration supervision, the generation of new income sources, and the use and diversification of local opportunities. In addition, these enterprises should be evaluated in terms of wealth matters such as efficiency in local service delivery, financial supervision, the competition in market economy, and corresponding of social choices. In this study, legal regulations constituting a basis for the establishment of MOEs, summarized the reasons and form of establishment, its structure, fields of activity, efficiency and productivity levels and used as an alternative delivering service method at the local level, and its application results will be examined.
\end{abstract}

Keywords: Local Service Delivery, Municipality-Owned Enterprises, Corporatization, Supervision

JEL Code: H41, H72

\section{Introduction}

The duties of municipalities established in order to meet the common needs of people living in a certain region from transportation to landscaping, from public health to sports facilities, from cultural activities and facilities to parking lots and many other services are given in detail both in the Metropolitan Municipality Law no. 5216 and Municipality Law no. 5393, a statement "it fulfills all services regarding inhabitants is given, and the limits of duties stated in the law is extended majorly. In this respect, it can be said that municipalities of various sizes try to provide public, semi-public goods and services at the local level related to local people and some other goods and services for the market. Due to the relevant regulations tried to be structured by taking each detail that municipalities may need during delivering all these services, it is provided that they can provide the necessary services to inhabitants without any legal obstacle. In other words, there is no legal obstacle that the municipalities face for the

\footnotetext{
1 Prof., Istanbul University, Faculty of Economics, cak@istanbul.edu.tr

2 Prof., Istanbul University, Faculty of Economics, binhan@istanbul.edu.tr

3 Res. Asst., Istanbul University, Faculty of Economics, volkan.oghan@istanbul.edu.tr
} 
realization of any service that will increase the welfare of the inhabitants. In spite of this comfort in the legal framework, it is observed that alternative and indirect service delivery methods are frequently used by presenting different reasons instead of performing directly through the municipality in providing some services in today's municipality practices. The first one of these relevant methods is the supply of various goods and services by means of Municipality-Owned Enterprises (MOEs) or partnership and association. Indeed, the consistency of the application results of this method used by introducing many reasons as it increases the efficiency level of supplied services, economization from the resources used, and even the generation of new resource with relevant discourses constitutes the basis of this study.

\section{The Concept of Municipality-Owned Enterprise}

In addition to the implementation of local services within the scope of public benefit, local governments can produce and deliver goods and services to the market through affiliated enterprises or companies established within the framework of the Turkish Commercial Code in order to stimulate economic life at local level, increase employment and generate income for local government units (Yılmaz et al., 2012: 64).

While more than half of the capital belongs to a municipality, MOEs are defined as legal entities of private law that the municipality keeps the administrations, operates in any subject that fall into the remit of municipality, has an independent budget than the municipality, utilizes supplies within the framework of Public Procurement Law provisions no. 4734, has spending and loan subjected to the $63^{\text {rd }}$ article of Municipal Law no. 5393, and has accountability to the Court of Accounts with Law on the Courts of Accounts no. 6085. With another definition, MOEs are defined as companies established by the municipalities, that their property and supervision belong to the municipality, their board of directors are appointed by the municipalities, finance their recurring expenditure with the revenues earned from their own funds and activities, provide the production or introduction of private goods and services in the priority of public benefit (Akalın, 1994: 17).

\section{Reasons of Establishment of Municipality-Owned Enterprises}

When we look at the reasons of existence of MOEs, used as a way of municipality service in the direction of contribution directly to local development and indirectly to national development and to present local services with a flexible and effective structure and process (Berk, 2003: 52), it is seen that the some reasons are related to the prevention of possible bureaucratic obstacles when encountered during the provision of services. Delays and procrastination resulting from bureaucracy and situations that may be encountered as a result of the tendencies of bureaucrats who cannot take risks may hamper service delivery in the case of providing some services which are obligatory to be met for the needs of local people. It is known that the current tendency to take the risk in the public sector is one of the reasons for privatization; in cases where urgent decisions are required, the existence of such structures having the flexibility of a company is thought to greatly facilitate the work of the municipalities.

Apart from the salary policy of the municipality budget, it is also aimed to assign the task to MOEs in the employment of qualified personnel with the characteristics that are expected to be performed in the best way. In this way, it is argued that the utilization of MOEs in the provision of employment will be helpful in the efficiency and the employment of the competent workers. 
The argument that MOEs can be used actively to be able to reduce the transfer of some of the public funds emerging as a result of delivering certain services through companies in service in the private sector constitutes another reason. In this way, the idea that municipalities can convert some of the cost elements they are obliged to produce service by means of MOEs constitutes the basis for the use of MOEs in these services.

Nowadays, municipalities can easily meet the needs of private sector from café, restaurant management to bread production by means of MOEs and municipality partnerships, and it is thought that it serves important purposes such as successful, standardized, and delivering low cost goods and services by MOEs and partnerships. Another reason is the idea that these relevant companies specialize in the jobs they do over time, make important contributions to the $R \& D$ activities related to the business and also have the qualifications to operate outside of the local boundaries. Thus, it is assumed that MOEs and partnerships, that can produce goods and services in exchange for price for nationwide and even abroad, can reach significant incomes.

Another reason that is argued MOEs and partnerships provide for municipalities and is constitutive for their establishment, is the assertion that they will contribute to the formation of competitive prices in delivering goods and services for public. Therefore, it is stated that municipalities may have great savings opportunities even in the services which are not directly fulfilled by their partnerships or MOEs.

In the utilization of large projects of MOEs and partnerships, the fact that banks can benefit from the credit facilities offered to capital companies is among the reasons for establishing MOEs by municipalities. Thus, the assumption that many investments that may be necessary to be provided and which may be profitable in the future can be realized more smoothly through accessible credit facilities are one of the reasons regarding establishment of MOEs. Besides, the idea that municipalities will be able to access new resources through privatization and going public of MOEs developing over time and their partnership is among the thoughts expressed.

All of these reasons should serve the highest purpose of public benefit. Although the concept of public benefit is not a concept that encompasses all sectors that constitutes the society, it connotes an application that is in favor of the majority comparatively. If the results of the application are determined to be in this way, and the results are reverse while this method should be extended to the wider segments, its reasons and results should be revealed.

\section{The Problem of Efficiency, Supervision, and Competition Created by Municipality- Owned Enterprises}

\subsection{The Determinations in terms of Regulations}

MOEs have regulation shortcomings in terms of efficiency, supervision and competition. The biggest problem encountered in practice is that regular independent reports and data of these enterprises are not shared with the public. If the mentioned municipal incorporations or their affiliates are highly acclaimed and are engaged in activities that maximize the public benefit and no one can appeal, why are the details of their expenditures not as open and transparent as any company whose shares are traded on the stock exchange? Moreover, we have started to receive some partial information of these companies with a number of implementation results that are reflected in the Court of Accounts reports after 2013. 
Municipalities can show a tendency to expansion for the purpose of being out of control by corporatization, establishing an Assoc.d company, partnering with established companies and continue their activities by availing to managers and pressure groups even in the case of lossmaking during current period. (T.C. Ministry of Development, 2014: 158). In this regard, the supervision of such initiatives by municipalities constitutes an important issue to be considered. Article 4 of the Law on the Turkish Court of Accounts no. 6085 includes all the administration, organization, establishment, association, operation and companies, which are affiliated to the municipalities that are not subject to external audit until 2013 amendment, within the scope of the Court of Auditors audit, established by the municipalities or directly or indirectly partnered. However, the fact that the effort to reduce the load of legal processes, which is the purpose for the establishment of MOEs in relevant law, contradiction with the issue regarding the generation of a flexible area of activity for municipalities (Karabilgin, 1992: 24), the effect of the external auditing to be realized on financial efficiency and service productivity may have negative consequences.

In order to ensure the return of the funds transferred from the public sector to the private sector to the municipalities (State Planning Organization, 2001: 88), there is an ongoing debate regarding the lack of a restriction on the municipal corporations to enter municipal tenders under the Public Procurement Law no. 4374. Article 5 of the related law states that the contracting authorities must meet the requirements such as transparency, competition, equal treatment, credibility, public opinion, efficiency, and optimal resource utilization for the tenders. However, in the case that the municipal corporations are included in the tenders realized by the open tender procedure in accordance with the law, other companies do not participate in the tender or cannot enter due to the existing preventive provisions in the technical specifications (Meşe, 2011: 211). In practice, it is seen that the number of tenders of municipality-owned companies in municipality tenders proves this situation and in particular it is at a level that would undermine the provisions of competition and equal treatment (ilhan, 2013: 10). The excess of such practices harms the market economy, and the cheapness provided in the inputs prior to service delivery may lead to a reduction in the local public benefit by causing a possible poor quality. On the other hand, the fact that municipalities that has the financial and administrative autonomy according to the legal basis, and its decision-making bodies are determined by the electorate realize the service delivery by establishing companies in the direction of the representation of the voter may lead to bureaucratic preferences instead of electoral preferences; in other words, it may lead to principal-agent problem.

Thus, when we look at the factors such as the formation of more competitive prices in the tenders that motivated the establishment of the company at the first stage, the saving of the public funds, employing of the competent personnel who know the work, it is understood that none of these goals were realized, only the legal supervision process did not work and a structure based on arbitrariness was formed. As things stand, an employment in line with the dominant thought that directs the politics is aimed, which is obvious that it is not in favor of public benefit and finances the politics in a sense. When municipality and corporate incomes for the local public benefit by the structure MOE and partnerships with specified reasons, it must be either to be ended immediately or the structure must be corrected rapidly. At the first stage, municipal corporations, which are also subject to the provisions of the Turkish Commercial Code, should be financed from municipal revenues in the case of damage. 


\subsection{The Determinations regarding İstanbul Metropolitan Municipality Application}

In order to obtain concrete information about the activities of MOEs and partnerships, which undertook the delivery of goods and services to the people towards local public benefit, when we consider the case of Istanbul Metropolitan Municipality, only partial data of these companies can be reached in the activity reports of the Municipality. However, in order to understand whether an activity is of public benefit or not, we need to have detailed information about the activity. So, some sub-elements such as transparency and accountability, which we believe to be within the scope of the concept of public benefit, cannot be found from the beginning in the case of Istanbul Metropolitan Municipality.

Table 1. İstanbul Metropolitan Municipality Data regarding MOEs and Partnerships

\begin{tabular}{|c|c|c|c|c|c|c|}
\hline Years & $\begin{array}{c}\text { Number of } \\
\text { Companies }\end{array}$ & Revenues (TL) & $\begin{array}{c}\text { Expenditures } \\
\text { (TL) }\end{array}$ & $\begin{array}{c}\text { Number of } \\
\text { Employees }\end{array}$ & $\begin{array}{c}\text { Employee } \\
\text { Growth } \\
\text { Rate (\%) }\end{array}$ & $\begin{array}{c}\text { Profitabality } \\
\text { Rate (\%) }\end{array}$ \\
\hline 2011 & 24 & 6.532 .260 .935 & 5.976 .665 .869 & 12.092 & - & 8,51 \\
\hline 2012 & 25 & 7.399 .667 .147 & 6.736 .903 .840 & 12.789 & 5,76 & 8,96 \\
\hline 2013 & 25 & 9.000 .385 .675 & 9.449 .989 .725 & 14.713 & 15,04 & $-5,00$ \\
\hline 2014 & 26 & 9.247 .619 .274 & 8.756 .976 .666 & $\mathbf{2 3 . 2 8 4}$ & $\mathbf{5 8 , 2 5}$ & 5,31 \\
\hline 2015 & 26 & 12.093 .108 .862 & 10.744 .815 .224 & 25.135 & 7,95 & 11,15 \\
\hline 2016 & 26 & 13.364 .821 .537 & 12.139 .902 .334 & 26.374 & 4,93 & 9,17 \\
\hline 2017 & 28 & 15.361 .269 .321 & 14.427 .314 .654 & 28.673 & 8,72 & 6,08 \\
\hline
\end{tabular}

Source: Relevant Years İstanbul Metropolitan Municipality are created through Activity Reports by us.

According to the Table 1, while 14,713 people are employed in 28 companies in Istanbul Metropolitan Municipality in a total of 28 companies in 2013, 28,673 people are employed in 2017. At the same time, the number of employees in Istanbul Metropolitan Municipality is 13.174-13.488. By means of these data, it is concluded that most of the municipal services are carried out through companies. It is also understood that the companies are used as a partial employment warehouses, just as in the case of Government Business Enterprises at one time by looking out for the benefit of a part of public. In addition, the sudden increase observed in the personnel employment by companies in 2014, when the previous local elections were held, strengthens our argument. In that case, the claim that companies belonging to a municipality generating income from all the local people make employment planning for only a certain part of the population and that an evaluation based on the quality of the service is not considered when making this planning gains strength. Of course, if there is data to prove that this claim is not true, the necessary academic measurement can be carried out easily.

When we look at the profitability ratios of the increasing number of MOEs and partnerships, it is observed that the number of those who gain profit and loss on the basis of companies is almost equal and they make an average profit of 6.3\% between the years 2011-2017 in total (Table 1). Losses are financed by the municipalities in the case that these companies lose money. There is no bankruptcy organization. Therefore, the lack of profit motive and the organization of bankruptcy, which are one of the privatization reasons we all know, is also generally valid 
for MOEs and its partnerships, and their position in the local public governments should be questioned. As stated by some of the thinkers in this field, the idea that they consults MOEs and affiliates as a solution as a result of the insufficiency of income while performing the activities of municipalities does not comply with the reality in this situation. Because companies do not seem profitable.

- When the reports of the Court of Accounts in different years are examined, following findings can be reached:

- Instead of being deposited in the municipality account of the dividends generated in the companies, it is continued to be used by companies; thus, interest-free capital are made used by companies.

- The management of the advertising units in the parking areas and public transportation areas are given to the companies instead of the municipalities,

- The immovable properties, which their operating right is transferred to the metropolitan municipal corporations, are transferred to the third parties without any tender.

- The assistance provided to the county municipalities by the metropolitan municipality is obtained from the metropolitan municipal companies without tender.

- The municipalities buy assets more costly than their own companies and the price is not made below enough regarding approximate cost (compared to a private sector firm operating in the same sector),

- Tenders that are won are given to third companies with subcontracts,

- Compared to the situation that municipal corporations participate in municipal tenders, it is seen that there are many issues observed in which fewer companies participated in tenders when the municipal corporations do not participate to the municipal tenders.

The legal and administrative structure that distributes the surpluses generated to the stakeholders and the loss to the public and make extra effort to minimize the profitability should be corrected immediately and the bankruptcy organization should be brought together with responsibility.

\section{Conclusion}

Despite the privatization flows that are realized in the public sector in various extents after 1980s, the majority of municipalities that offer public and semi-public services and goods that are of local qualities benefit from incorporated companies while providing such services. Certain factors, such as effective allocation of resources in providing services, elasticity and practicability, are shown as the main reasons for the situation. However, whether there is an accord between the results of the implementation and these reasons must be questioned with the perspective of public benefit. If services are provided in cheaper, more effective, and faster ways through the mentioned reasons, there may be a need for generalizations of such services among the public sector. That said, many MOEs seem to be losing money does not correlate with the main purpose of such municipality enterprises. In this respect, compulsory transfer financial resources from the public sector in case of loss, as well as non-compulsory transfer of resources to the public sector in case of profit, seem to clarify the losses in the activity reports. That such municipality enterprises providing benefits for administrative managers or employees more than for the 
public service creates problem regarding the ineffective and ambiguous allocation of public resources. In relation to the mentioned reasons, conducting such an implementation in the way of maximizing public benefit requires transparent management and operation mechanisms, merit based administration and employment structures, and an effective controlling system.

\section{References}

Akalın, G. (1994). "Yerel Yönetimlerin İktisadi Teşebbüslerinin Özelleştirilmesi”, Çağdaş Yerel Yönetimler Dergisi, 3 (6), pp. 15-27.

Berk, A. (2003). "Yerel Hizmet Sunumu ve Belediye İktisadi Teşebbüsleri”, Sayıştay Dergisi, (49). ss. 47-63.

Belediye Kanunu. Kanun Numarası: 5393. Kabul Tarihi: 3/7/2005. Yayımlandığı R. Gazete: Tarih: 13/7/2005 Sayı: 25874, Yayımlandığı Düstur: Tertip: 5, Cilt: 44.

Büyükşehir Belediye Kanunu. Kanun Numarası: 5216. Kabul Tarihi: 10/7/2004. Yayımlandığı R. Gazete: Tarih: 23/7/2004 Sayı: 25531, Yayımlandığı Düstur: Tertip: 5. Cilt: 43.

Çak, M. \& D. Çak (2012). “Devlet Üniversitelerine Yeni Mali Kaynak Arayışları: Üniversite Şirketleri Modeli". Maliye Araştırma Merkezi Konferansları, (58-2). pp. 27-50.

Devlet Planlama Teşkilatı (2001). Sekizinci Beş Yıllık Kalkınma Planı (2001-2005): Yerel Yönetimler Özel ihtisas Raporu, Yayın No: 2538. Ankara.

İlhan, i̇. (2013). "Türkiye'de Belediyeler ve Şirketler Arasında İhale İlişkileri Üzerine Bir Araşttrma”, Sayıştay Dergisi, (88). pp. 5-25.

İstanbul Büyükşehir Belediyesi, Faaliyet Raporları.

Kamu ihale Kanunu. Kanun Numarası: 4374. Kabul Tarihi: 4/1/2002. Yayımlandığı R. Gazete: Tarih: 22/1/2002 Sayı: 24648, Yayımlandığı Düstur: Tertip: 5. Cilt: 42.

Karabilgin, A. (1992). "Yerel Yönetimlerin Ekonomik Girişimleri", Çağdaş Yerel Yönetimler Dergisi, pp. 21-25.

Meşe, M. (2011). “Belediye Şirketleri Üzerine Bir Değerlendirme”, Dış Denetim Dergisi, pp. 203-215.

Sayıştay Kanunu. Kanun Numarası: 6085. Kabul Tarihi: 3/12/2010. Yayımlandığı R. Gazete: Tarih: 19/12/2010 Sayı: 27790, Yayımlandığı Düstur: Tertip: 5. Cilt: 50.

T.C. Kalkınma Bakanlığı (2014). Onuncu Kalkınma Planı (2014-2018): Yerel Yönetimler Özel Ihtisas Komisyonu Raporu, Yayın No: 2868, Ankara.

Yılmaz, H. H., Emil, M. F., \& Kerimoğlu, B. (2012). Yerel Yönetimler Maliyesi: Temel Illkeler Ile Mevzuat ve Uygulama Açısından Türk Yerel Yönetim Yapılanmasında Mali Yönetim ve Kaynak Kullanım Sistemi, Mali Hizmetler Derneği, Ankara. 